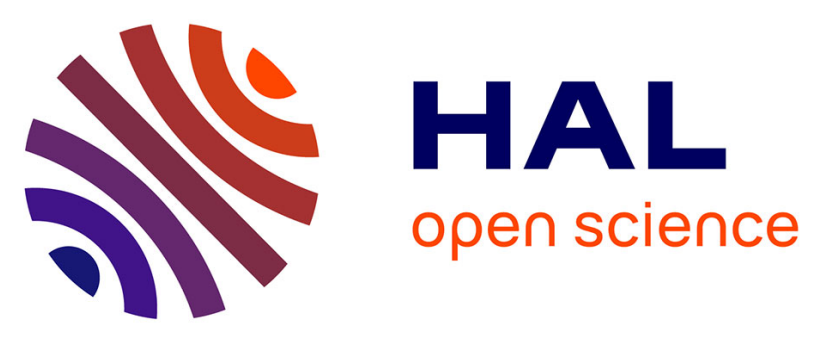

\title{
Surveillance with successful reduction of central line-associated bloodstream infections among neutropenic patients with hematologic or oncologic malignancies
}

Iris F. Chaberny, Evelina Ruseva, Dorit Sohr, Stefanie Buchholz, Arnold Ganser, Frauke Mattner, Petra Gastmeier

\section{To cite this version:}

Iris F. Chaberny, Evelina Ruseva, Dorit Sohr, Stefanie Buchholz, Arnold Ganser, et al.. Surveillance with successful reduction of central line-associated bloodstream infections among neutropenic patients with hematologic or oncologic malignancies. Annals of Hematology, 2009, 88 (9), pp.907-912. 10.1007/s00277-008-0687-1 . hal-00535023

\section{HAL Id: hal-00535023 \\ https://hal.science/hal-00535023}

Submitted on 11 Nov 2010

HAL is a multi-disciplinary open access archive for the deposit and dissemination of scientific research documents, whether they are published or not. The documents may come from teaching and research institutions in France or abroad, or from public or private research centers.
L'archive ouverte pluridisciplinaire HAL, est destinée au dépôt et à la diffusion de documents scientifiques de niveau recherche, publiés ou non, émanant des établissements d'enseignement et de recherche français ou étrangers, des laboratoires publics ou privés. 


\title{
Surveillance with successful reduction of central line-associated bloodstream infections among neutropenic patients with hematologic or oncologic malignancies
}

\author{
Iris F. Chaberny $\cdot$ Evelina Ruseva $\cdot$ Dorit Sohr • \\ Stefanie Buchholz • Arnold Ganser • Frauke Mattner • \\ Petra Gastmeier
}

Received: 5 July 2008 /Accepted: 18 December 2008 /Published online: 13 January 2009

(C) Springer-Verlag 2009

\begin{abstract}
To determine nosocomial catheter-associated bloodstream infections (CA-BSIs) and to improve the prevention measures, we performed a prospective surveillance in our hematopoietic stem cell transplantation unit at our university hospital. During the 36-month study period all patients with at least two consecutive neutropenic days (NDs) were included. After the first 18 months the recorded data were analyzed and compared with reference data and were then presented to the clinical staff. An intensive training to improve the handling of central venous lines was performed afterwards. At the end of the last 18-month study period the data were evaluated and a multivariate analysis was conducted. Altogether 268 patients were treated for a period of 10,013 patient days including 4,286 NDs. A total of 202/268 (75.4\%) patients underwent transplantation (157/76.6\% allogeneic, 48/23.4\% autologous). Eighty-seven CA-BSIs were identified. The incidence density was 24.3 CA-BSI episodes per 1,000 NDs in the first period and 16.2 in the second. A significant reduction
\end{abstract}

I. F. Chaberny $(\bowtie) \cdot$ E. Ruseva $\cdot$ F. Mattner $\cdot$ P. Gastmeier Institute of Medical Microbiology and Hospital Epidemiology,

Hannover Medical School,

Carl-Neuberg-Str. 1,

30625 Hannover, Germany

e-mail: chaberny.iris@mh-hannover.de

D. Sohr

Institute of Hygiene and Environmental Medicine,

Charité-University Medicine Berlin,

Hindenburgdamm 27,

12203 Berlin, Germany

S. Buchholz $\cdot$ A. Ganser

Department of Hematology, Hemostasis, Oncology and Stem Cell

Transplantation, Hannover Medical School,

Carl-Neuberg-Str. 1,

30625 Hannover, Germany in the CA-BSI rate of adults was achieved (OR 0.58; $95 \%$ CI $0.339-0.987 ; p<0.05$ ). Significant risk factors for nosocomial CA-BSIs during the neutropenic phase were AML as underlying disease as well as transplantations.

Keywords Surveillance $\cdot$ Neutropenia $\cdot$ Nosocomial . Bloodstream infection

\section{Introduction}

Central line-associated bloodstream infections (CA-BSIs) are associated with significant morbidity, mortality, and costs [1-3]. A special high risk patient group for CA-BSIs are the hematological oncology patients, because nearly $100 \%$ of these patients require indwelling central venous catheters for therapy and keep them during neutropenic episodes. Eighty-two percent of all infectious complications in patients undergoing hematopoietic stem cell transplantation appear during the neutropenic phase [4]. In addition, $65 \%$ of catheter-associated infectious episodes occur during neutropenia in recipients of bone marrow transplants [5]. Hence, the neutropenic phase represents a significantly high risk factor for cancer patients to acquire nosocomial infections. This was already described by Carlisle and other authors [6-8].

Therefore, a prospective surveillance for nosocomial infections during the neutropenic phase is an essential quality requirement for the treatment of patients with hematological malignancies to improve infection prevention measures.

The aim of this study was to introduce a prospective surveillance system for nosocomial CA-BSI, in order to improve prevention measures and to reduce this type of nosocomial infections in patients with hematological 
oncological malignancies during neutropenia in a hematopoietic stem cell transplantation (HSCT) unit.

\section{Materials and methods}

Setting and study population

Hannover Medical School is a 1,400-bed university hospital in Germany. During the study period the HSCT unit was an interdisciplinary 20-bed ward (17 beds were occupied by adult patients and three beds by pediatric patients). This unit was built and opened at the beginning of 2001. Current recommendations have been taken into account for the construction of this new ward with HEPA air filtration and positive air pressure reverse isolation [9].

The study was conducted from May 2001 until April 2004 and included all adult inpatients who became neutropenic for at least two consecutive days due to their treatment in this unit.

\section{Surveillance method}

We decided to survey nosocomial bloodstream infections in adults ( $>18$ years) in accordance with the ONKO-KISS protocol during neutropenia at our hospital [10]. This protocol was applied as part of the surveillance program of the German Hospital Infection Surveillance System (KISS). This module was introduced in the year 2000. Meanwhile, about 24 participating national and international centers for bone marrow transplantation from German speaking countries (Germany, Suisse, and Austria) have sent their data each year. Nosocomial CA-BSIs were diagnosed according to Centers for Disease Control and Prevention definitions that include clinical and laboratory criteria [11]. The CA-BSIs were recorded by the infection control team of the Hannover Medical School regardless of whether the patients had undergone HSCT or not.

Neutropenia was defined as the absolute white blood cell count being less than $1 \times 10^{9}$ cells/ $\mathrm{L}$ for at least 2 days, since at this time the absolute neutrophil count definitely was $<1,000 / \mu \mathrm{L}$ even in the absence of a differential count. The neutropenic phase was declared to have ended once the patient had a neutrophil count $>1 \times 10^{9}$ cells $/ \mathrm{L}$ for at least 2 days. Nosocomial bloodstream infections that occurred during the neutropenic phase were recorded. An infection was only classified as being nosocomial if there was clear evidence that - at the point of admission to the ward - the infection had been neither active nor incubating. In addition, an infection was considered to be nosocomial if symptoms appeared at any time on or after the second day after the onset of neutropenia up to 2 days after the end of neutropenia.
During the neutropenic phase parameters and characteristics of the patients such as age, gender, underlying disease, relapse of disease, devices, transplantation, and type of transplantation were collected during their hospital stays.

\section{Intervention}

After the first 18 months of surveillance (May, 2001October, 2002) the nosocomial incidence rates for CA-BSI were calculated. Compared with reference data the rates were presented to the healthcare workers in the ward. Within the following weeks an intensive training course was conducted for the clinical staff to improve the prevention measures concerning the handling of central venous lines according to national and international guidelines $[12,13]$.

Instead of gauzes only transparent semi-permeable dressings were used consequently and changed at least every 7 days or when it became damp, soiled, or loosened. All other recommended prevention measures were reinforced and improved consequently by education, particularly hand disinfection before donning or after removing gloves.

In addition, an improved standard operating procedure protocol for dealing with central venous lines was worked out and introduced into the routine nursing care of the ward. The formerly used non-impregnated central venous catheters were replaced by chlorhexidine-silversulfadiazine impregnated catheters (first generation) which were coated on the outer catheter surface.

\section{Data analysis}

The data were entered into Microsoft Excel (Microsoft, Redmond, WA, USA). Incidences (episodes per 100 patients) and incidence densities of nosocomial bloodstream infections per 1,000 neutropenic days were calculated [10]. Incidence densities were compared using the exponential maximum likelihood estimation test. Categorical variables were compared using chi-square or Fisher's exact test as appropriate.

To identify risk factors for CA-BSI a multivariate analysis was done by sequential backward stepwise elimination. All statistical tests were considered significant if the $p$-value was $\leq 0.05$. Statistical analyses were performed using SAS software (SAS Institutes, Cary, NC).

\section{Results}

Patients

Throughout the 36 months of observation from May, 2001 to April, 2004, altogether 268 patients were treated on the HSCT unit at the Hannover Medical School during 10,013 
patient days which included 4,286 (42.8\%) neutropenic days. A total number of 280 neutropenic episodes were observed among these 268 patients. The mean length of stay on the unit of the study group was 37.4 days (median, 33.0 days; range, 7-168 days).

A total of $202 / 268(75.4 \%)$ patients underwent transplantations. Of these, $157(76.6 \%)$ patients received allogeneic and $48(23.4 \%)$ patients obtained autologous transplantations. The duration of neutropenic episodes varied among different types of transplantation and in comparison to those patients without any transplantation (see Table 1).

Throughout the study period no changes in the antiinfective prophylaxis protocols were noticed.

\section{Bloodstream infections}

Eighty-eight CA-BSIs were recorded in 87 patients, i.e. one patient suffered two episodes of CA-BSI during his hospital stay on the ward. For further data evaluation only the first sepsis episodes were taken into account in the risk factor analysis. The mean length of stay on the unit of these BSIpatients was 41.1 days (median, 35.0 days; range, 9127 days).

During the neutropenic phase, central venous lines were present in $97.8 \%(262 / 268)$ of the neutropenic patients. A non-tunneled central venous catheter was used in 258 patients of whom 86 (33.3\%) suffered a sepsis. An existing totally implantable port system was used in four patients of whom one patient suffered an episode of CA-BSI. Six patients did not have any central venous access during neutropenia phase and they did not suffer from any sepsis.

The average time from the beginning of neutropenia to the first positive blood culture was 9.8 days (median 7 days, range 1 to 82 days). Of the 87 relevant bacterial isolates, 66 $(75.9 \%)$ were gram-positive bacteria, 13 (14.9\%) were gram-negative bacteria, four $(4.6 \%)$ were yeasts, two $(2.3 \%)$ were other cocci, one $(1.1 \%)$ was Corynebacterium spp., and one (1.1\%) was an anaerobe pathogen. Polymicrobial bacteremia was found in 14 patients.

No differences in the kind of infections concerning gram-positive and gram-negative bacteria were noticed between pre- and post-intervention period.
Intervention and reference data

The calculated incidence rates are presented in Table 2. In comparison with the reference data of ONKO-KISS-18 hospitals were participating in this module at the date of analysis - the rate of 24.3 for nosocomial CA-BSIs per 1,000 neutropenic days showed an outlier position above the 75 th percentile (20.3) to the reference rate with a median of 17.7 in the first study period (period A) [10]. After intervention the rate decreased to 16.2 nosocomial CA-BSIs per 1,000 neutropenic days and showed a position below the median (17.7) compared to the reference data. This reduction was significant (OR 0.58 ; 95\% CI 0.34 0.99) (see Table 3).

Risk factor analysis

The characteristics of the study population and the results of the univariate risk factor analysis are presented in Table 3. During multivariate analysis, variables independently associated with a CA-BSI were transplantation (OR 2.11; 95\% CI, 1.10-4.26) and acute myeloid leukemia (AML) (OR 1.92; 95\% CI, 1.12-3.32).

\section{Discussion}

The recently published article of Pronovost et al. has demonstrated that an evidence-based intervention resulted in a large and sustained reduction up to $66 \%$ in rates of catheter-associated BSIs in ICUs [14]. Several other studies described reduction rates of $14 \%$ to $71 \%$ on ICUs, e.g. surgical ICUs, neonatological ICUs, and hospital-wide. The authors of all these studies performed a surveillance with feedback and education programs [15-21]. Reduction rates of $41 \%$ to $100 \%$ in CA-BSIs were discussed in further studies [22-24]. The elimination of CA-BSIs was achieved with continuous training programs which included lectures, posters, fact sheets, self-study programs for health care workers, and a review with pre- and post-tests [24]. The duration of 4 years needed for the introduction of these measures as well as their evaluation is one characteristic of the latter.

Table 1 Duration of neutropenic episodes according to the different types of transplantation or to no transplantation

\begin{tabular}{|c|c|c|c|c|c|c|}
\hline \multirow[t]{2}{*}{ Type of transplantation } & \multirow[t]{2}{*}{ Total no. of patients } & \multirow[t]{2}{*}{ Total no. of neutropenic days } & \multicolumn{4}{|c|}{ Duration of neutropenic phase } \\
\hline & & & Mean & Min & Median & Max \\
\hline Allogeneic transplant recipients & 154 & 2,764 & 17.2 & 2.0 & 15.0 & 85.0 \\
\hline Autologous transplant recipients & 48 & 508 & 10.6 & 4.0 & 8.0 & 99.0 \\
\hline Patients without transplantation & 66 & 1,014 & 15.4 & 2.0 & 11.0 & 57.0 \\
\hline Total & 268 & 4,286 & 16.0 & 2.0 & 13.0 & 99.0 \\
\hline
\end{tabular}


Table 2 Comparison of the two study periods $(\mathrm{A}=$ basic period and $\mathrm{B}=$ after intervention) among all patients

\begin{tabular}{lrrr}
\hline Interventions & $\begin{array}{c}\text { Period A } \\
\text { Before }\end{array}$ & $\begin{array}{l}\text { Period B } \\
\text { After }\end{array}$ & Total \\
\hline Duration (month) & 18 & 18 & 36 \\
Patients & 138 & 130 & 268 \\
Neutropenic days & 2,184 & 2,102 & 4,286 \\
Bloodstream infections (BSI) & 53 & 34 & 87 \\
Incidence density, BSI episodes per & 24.3 & 16.2 & 20.3 \\
1,000 neutropenic days & & & \\
Rate, BSI episodes per 100 patients & 38.4 & 26.2 & 32.5 \\
\hline
\end{tabular}

To our knowledge, our study is the first to show a reduction of infection rates in patients with hematological malignancies after the implementation of surveillance with feedback and following training. Due to the implementation of these prevention measures during a time as short as 18 months, we achieved a significant reduction of $35.8 \%$ of
CA-BSI episodes per 1,000 neutropenic days at the end of this observation period. Our successful efforts were not as impressive as described by Beerenholtz et al. [24]. Therefore, it is probably possible to achieve even much better reduction rates. However, the question remains whether this infection rate can be reduced to a sustained zero-rate in this high-risk patient group.

The duration of neutropenic phases caused by chemotherapy represents an important risk factor for acquiring nosocomial infections independently of undergoing a HSCT [25-27]. In our study we demonstrated that the main significant risk factors for nosocomial CA-BSI acquired during neutropenia are transplantation and the diagnosis and treatment for an AML. With $42.2 \%$, patients with this underlying disease represent the main patient population of our study group. The recently published article of Meyer et al. shows similar results in patients with advanced AML who had an increased risk of CA-BSI [28]. However, patients with the diagnosis and treatment for

Table 3 Frequency of nosocomial catheter-associated bloodstream infection (CA-BSI) depending on patient characteristics and intrinsic risk factors in the study group $(n=268)$

\begin{tabular}{|c|c|c|c|c|c|c|}
\hline \multirow[t]{2}{*}{ Factor } & \multirow{2}{*}{$\begin{array}{l}\text { Total no. of patients } \\
\text { No. }\end{array}$} & \multicolumn{2}{|c|}{$\begin{array}{l}\text { No. of patients } \\
\text { with CA-BSI }\end{array}$} & \multirow[t]{2}{*}{ OR $(95 \% \mathrm{CI})$} & \multirow[t]{2}{*}{$\begin{array}{l}p \text { on univariate } \\
\text { analysis }\end{array}$} & \multirow[t]{2}{*}{$\begin{array}{l}\text { Multivariate analysis }{ }^{\mathrm{a}} \mathrm{OR} \\
(95 \% \mathrm{CI})\end{array}$} \\
\hline & & No. & $(\%)$ & & & \\
\hline Age $\geq 49$ & 141 & 48 & $(34.0)$ & $1.17(0.70-1.95)$ & 0.60 & \\
\hline Gender, male & 152 & 53 & $(34.9)$ & $1.29(0.77-2.17)$ & 0.36 & \\
\hline \multicolumn{7}{|l|}{ Underlying disease } \\
\hline Acute myeloid leukemia & 113 & 44 & $(38.9)$ & $1.66(0.99-2.78)$ & 0.06 & $1.92(1.12-3.32)$ \\
\hline Acute lymphocytic leukemia & 40 & 16 & $(40.0)$ & $1.47(0.74-2.95)$ & 0.28 & \\
\hline Plasmacytoma & 36 & 9 & $(25.0)$ & $0.66(0.30-1.47)$ & 0.34 & \\
\hline Chronic myeloid leukemia & 31 & 6 & (19.4) & $0.46(0.18-1.17)$ & 0.11 & \\
\hline Non-Hodgkin lymphoma & 20 & 4 & $(20.0)$ & $0.50(0.16-1.53)$ & 0.32 & \\
\hline Myelodysplastic syndrome & 3 & 2 & $(66.7)$ & $4.24(0.38-47.4)$ & 0.25 & \\
\hline Other & 25 & 6 & $(24.0)$ & $0.63(0.24-1.64)$ & 0.38 & \\
\hline Treatment of relapse & 90 & 33 & $(36.7)$ & $1.32(0.77-2.26)$ & 0.34 & \\
\hline Transplantation $^{\mathrm{b}}$ & 202 & 72 & $(35.6)$ & $1.88(0.99-3.58)$ & 0.07 & $2.11(1.10-4.26)$ \\
\hline \multicolumn{7}{|l|}{ Bone marrow transplant } \\
\hline Autologous & 1 & 0 & $(0.0)$ & - & 1.00 & \\
\hline Allogeneic sibling donor & 5 & 1 & $(20.0)$ & $0.52(0.06-4.67)$ & 1.00 & \\
\hline Matched unrelated donor & 17 & 7 & $(41.2)$ & $1.50(0.55-4.07)$ & 0.43 & \\
\hline \multicolumn{7}{|l|}{ Peripheral blood stem cells } \\
\hline Autologous & 47 & 11 & $(23.4)$ & $0.58(0.28-1.21)$ & 0.17 & \\
\hline Allogeneic sibling donor & 58 & 24 & (41.4) & $1.65(0.90-3.00)$ & 0.11 & \\
\hline Matched unrelated donor & 77 & 31 & $(40.3)$ & $1.63(0.94-2.82)$ & 0.09 & \\
\hline Central venous catheter & 258 & 86 & $(33.3)$ & $4.50(0.56-36.1)$ & 0.17 & \\
\hline Portsystem & 4 & 1 & $(25.0)$ & $0.69(0.07-6.73)$ & 1.00 & \\
\hline Without central device & 6 & 0 & $(0.0)$ & - & 0.10 & \\
\hline Study period B & 130 & 34 & $(26.2)$ & $0.57(0.34-0.96)$ & 0.04 & $0.58(0.34-0.99)$ \\
\hline
\end{tabular}

${ }^{\text {a }}$ Significance level $=0.05$ for entry into the model and stay in the model after stepwise variable selection; basis odds $=0.2574 c$-index $=0.623$

${ }^{\mathrm{b}}$ Two patients received more than one transplantation during their hospital-stay 
advanced disease did not represent a significant number in our patient group.

The study has several limitations. First, the observation period of catheter-associated bloodstream infections was only restricted to neutropenic episodes in each patient. Hence, we did not know how many CA-BSIs were missed during the whole hospital stay and we did not observe patients without a neutropenic episode which had to occur at least on two consecutive days. Another aspect of this restriction is the unavailable comparison with published international CA-BSI rates because these rates refer to the common catheter-days. However, over $70 \%$ to $80 \%$ of nosocomial infections occur during neutropenic episodes $[4,29]$. Hence, due to the restriction to high risk days - the neutropenic days - it is a time-saving effective method for surveillance of nosocomial infections among neutropenic patients. Meanwhile, 24 hospitals with bone marrow transplantation units from Germany, Suisse, and Austria participated in the ONKO-KISS module and provided their data to the national reference centre for surveillance of nosocomial infections (http://www.nrz-hygiene.de), which proves that the module i.e. the surveillance method is very well accepted.

Second, we did not evaluate compliance with the several trained procedures after intervention. Thus, we could not evaluate the relative importance of individual components of the multifaceted intervention.

The recently published systematic review of Niel-Weise et al. have shown that available scientific evidence to prevent CA-BSI by the use of antiseptic-treated CVCs in patients receiving chemotherapy is not sufficient as a basis to recommend their use [30]. A decade ago, Logghe et al. have demonstrated no statistically significant difference between the overall rates of BSI for impregnated and nonimpregnated catheters in patients with hematologic malignancy by a randomized controlled trial [31]. Therefore, our introduction of chlorhexidine-silversulfadiazine impregnated catheters could not be solely responsible for the significant reduction of CA-BSI rates.

Many studies have shown successful reduction rates of CA-BSI due to multifaceted interventions in several patient groups [14, 19, 23, 24]. A systematic review has even shown that studies investigating multi-module program, however, found a substantial reduction in CA-BSIs. Simple interventions are often useful for reducing CA-BSI rates and the opportunities to decrease CA-BSI rates appear to be greatest when multi-module programs are applied [32]. Hence, we could confirm these statements with our data in a vulnerable high-risk patient group.

However, the aim of this study was to improve prevention measures which could be demonstrated with a significant reduction. More reports on successful interventions will be needed to promote a continuous prospective surveillance of nosocomial CA-BSIs in this high-risk patient group and to motivate clinical staff to improve prevention measures [33].

\section{References}

1. Pittet D, Tarara D, Wenzel RP (1994) Nosocomial bloodstream infection in critically ill patients. Excess length of stay, extra costs, and attributable mortality. JAMA 271:1598-1601. doi:10.1001/ jama.271.20.1598

2. Laupland KB, Lee H, Gregson DB, Manns BJ (2006) Cost of intensive care unit-acquired bloodstream infections. J Hosp Infect 63:124-132. doi:10.1016/j.jhin.2005.12.016

3. Higuera F, Rangel-Frausto MS, Rosenthal VD, Soto JM, Castanon J, Franco G, Tabal-Galan N, Ruiz J, Duarte P, Graves N (2007) Attributable cost and length of stay for patients with central venous catheter-associated bloodstream infection in Mexico City intensive care units: a prospective, matched analysis. Infect Control Hosp Epidemiol 28:31-35. doi:10.1086/510812

4. Busca A, Saroglia EM, Giacchino M, Vai S, Vassallo E, Fagioli F, Linari A, Dotti G, Miniero R, Madon E (1999) Analysis of early infectious complications in pediatric patients undergoing bone marrow transplantation. Support Care Cancer 7:253-259. doi: $10.1007 / \mathrm{s} 005200050257$

5. Elishoov H, Or R, Strauss N, Engelhard D (1998) Nosocomial colonization, septicemia, and Hickman/Broviac catheter-related infections in bone marrow transplant recipients. A 5-year prospective study. Medicine (Baltimore) 77:83-101. doi:10.1097/00005792-199803000-00002

6. Carlisle PS, Gucalp R, Wiernik PH (1993) Nosocomial infections in neutropenic cancer patients. Infect Control Hosp Epidemiol 14:320-324

7. Ashkenazi S, Leibovici L, Samra Z, Konisberger H, Drucker M (1992) Risk factors for mortality due to bacteremia and fungemia in childhood. Clin Infect Dis 14:949-951

8. Guven GS, Uzun O, Cakir B, Akova M, Unal S (2006) Infectious complications in patients with hematological malignancies consulted by the infectious diseases team: a retrospective cohort study (1997-2001). Support Care Cancer 14:52-55. doi:10.1007/ s00520-005-0836-1

9. CDC (2000) Guidelines for preventing opportunistic infections among hematopoietic stem cell transplant recipients: recommendations of the Centers for Disease Control and Prevention, the Infectious Disease Society of America, and the American Society of Blood and Marrow Transplantation. MMWR Recomm Rep 49:1-125

10. Dettenkofer M, Wenzler-Rottele S, Babikir R, Bertz H, Ebner W, Meyer E, Ruden H, Gastmeier P, Daschner FD (2005) Surveillance of nosocomial sepsis and pneumonia in patients with a bone marrow or peripheral blood stem cell transplant: a multicenter project. Clin Infect Dis 40:926-931. doi:10.1086/428046

11. Gaynes RP, Horan TC (1999) Surveillance of nosocomial infections. Appendix A: CDC definitions of nosocomial infections. In: Mayhall CG (ed) Hospital epidemiology and infection control. 2nd edn. Lippincott, Williams \& Wilkins, Philadelphia, pp 1296-1307

12. O'Grady N, Alexander M, Patchen Dellinger E, Gerberding JL, Heard SO, Maki DG, Masur H, McCormick RD, Mermel LA, Pearson ML, Raad II, Randolph A, Weinstein RA (2002) Guidelines for the prevention of intravascular catheter-related infections. MMWR Recomm Rep 51:1-32

13. \Anonymous (2002) Prevention of vascular catheter-associated infections. Bundesgesundheitsbl 45:907-924. doi:10.1007/s00103002-0499-8 
14. Pronovost P, Needham D, Berenholtz S, Sinopoli D, Chu H, Cosgrove S, Sexton B, Hyzy R, Welsh R, Roth G, Bander J, Kepros J, Goeschel C (2006) An intervention to decrease catheterrelated bloodstream infections in the ICU. $N$ Engl $J$ Med 355:2725-2732. doi:10.1056/NEJMoa061115

15. Bijma R, Girbes AR, Kleijer DJ, Zwaveling JH (1999) Preventing central venous catheter-related infection in a surgical intensivecare unit. Infect Control Hosp Epidemiol 20:618-620. doi:10.1086/501682

16. Bishop-Kurylo D (1998) The clinical experience of continuous quality improvement in the neonatal intensive care unit. J Perinat Neonatal Nurs 12:51-57

17. Civetta JM, Hudson-Civetta J, Ball S (1996) Decreasing catheterrelated infection and hospital costs by continuous quality improvement. Crit Care Med 24:1660-1665. doi:10.1097/ 00003246-199610000-00010

18. Cohran J, Larson E, Roach H, Blane C, Pierce P (1996) Effect of intravascular surveillance and education program on rates of nosocomial bloodstream infections. Heart Lung 25:161-164. doi:10.1016/S0147-9563(96)80120-8

19. Eggimann P, Harbarth S, Constantin MN, Touveneau S, Chevrolet JC, Pittet D (2000) Impact of a prevention strategy targeted at vascular-access care on incidence of infections acquired in intensive care. Lancet 355:1864-1868. doi:10.1016/S0140-6736(00)02291-1

20. Maas A, Flament P, Pardou A, Deplano A, Dramaix M, Struelens MJ (1998) Central venous catheter-related bacteraemia in critically ill neonates: risk factors and impact of a prevention programme. J Hosp Infect 40:211-224. doi:10.1016/S0195-6701 (98)90139-6

21. Yoo S, Ha M, Choi D, Pai H (2001) Effectiveness of surveillance of central catheter-related bloodstream infection in an ICU in Korea. Infect Control Hosp Epidemiol 22:433-436. doi:10.1086/ 501930

22. Warren DK, Zack JE, Mayfield JL, Chen A, Prentice D, Fraser VJ, Kollef MH (2004) The effect of an education program on the incidence of central venous catheter-associated bloodstream infection in a medical ICU. Chest 126:1612-1618. doi:10.1378/chest. 126.5.1612

23. CDC (2005) Centers for disease control and prevention: reduction in central line-associated bloodstream infections among patients in intensive care units-Pennsylvania, April 2001-March 2005. MMWR 54:1013-1016

24. Berenholtz SM, Pronovost PJ, Lipsett PA, Hobson D, Earsing K, Farley JE, Milanovich S, Garrett-Mayer E, Winters BD, Rubin
HR, Dorman T, Perl TM (2004) Eliminating catheter-related bloodstream infections in the intensive care unit. Crit Care Med 32:2014-2020. doi:10.1097/01.CCM.0000142399.70913.2F

25. Cordonnier C, Buzyn A, Leverger G, Herbrecht R, Hunault M, Leclercq R, Bastuji-Garin S (2003) Epidemiology and risk factors for gram-positive coccal infections in neutropenia: toward a more targeted antibiotic strategy. Clin Infect Dis 36:149-158. doi:10.1086/345435

26. Pizzo PA (1999) Fever in immunocompromised patients. N Engl J Med 341:893-900. doi:10.1056/NEJM199909163411207

27. Santolaya ME, Alvarez AM, Aviles CL, Becker A, Cofre J, Enriquez N, O'Ryan M, Paya E, Salgado C, Silva P, Tordecilla J, Varas M, Villarroel M, Viviani T, Zubieta M (2002) Prospective evaluation of a model of prediction of invasive bacterial infection risk among children with cancer, fever, and neutropenia. Clin Infect Dis 35:678-683. doi:10.1086/342064

28. Meyer E, Beyersmann J, Bertz H, Wenzler-Rottele S, Babikir R, Schumacher M, Daschner FD, Ruden H, Dettenkofer M (2007) Risk factor analysis of blood stream infection and pneumonia in neutropenic patients after peripheral blood stem-cell transplantation. Bone Marrow Transplant 39:173-178. doi:10.1038/sj.bmt. 1705561

29. Dettenkofer M, Ebner W, Bertz H, Babikir R, Finke J, Frank U, Ruden H, Daschner FD (2003) Surveillance of nosocomial infections in adult recipients of allogeneic and autologous bone marrow and peripheral blood stem-cell transplantation. Bone Marrow Transplant 31:795-801. doi:10.1038/sj.bmt. 1703920

30. Niel-Weise BS, Stijnen T, van den Broek PJ (2008) Anti-infectivetreated central venous catheters for total parenteral nutrition or chemotherapy: a systematic review. J Hosp Infect 69:114-123. doi:10.1016/j.jhin.2008.02.020

31. Logghe C, Van Ossel C, D'Hoore W, Ezzedine H, Wauters G, Haxhe JJ (1997) Evaluation of chlorhexidine and silver-sulfadiazine impregnated central venous catheters for the prevention of bloodstream infection in leukaemic patients: a randomized controlled trial. J Hosp Infect 37:145-156. doi:10.1016/S0195-6701 (97)90184-5

32. Gastmeier P, Geffers C (2006) Prevention of catheter-related bloodstream infections: analysis of studies published between 2002 and 2005. J Hosp Infect 64:326-335. doi:10.1016/j.jhin. 2006.07.005

33. Richards C, Emori TG, Peavy G, Gaynes R (2001) Promoting quality through measurement of performance and response: prevention success stories. Emerg Infect Dis 7:299-301 